\title{
Pengaruh Peracunan Media dengan Asap Cair Tempurung Kelapa (Cocos nucifera) pada Pertumbuhan Jamur Colletotrichum sp. Penyebab Penyakit Busuk Buah Kakao
}

\author{
Agus Suyanto ${ }^{1, *)}$, Ismail Astar ${ }^{2}$, Agnes Tutik Purwani Irianti ${ }^{3}$, Meta Amalia ${ }^{4}$ \\ Universitas Panca Bhakti Pontianak, Indonesia \\ agussuyanto@upb.ac.id ${ }^{1}$, ismailastar@upb.ac.id ${ }^{2}$, agnestutik@upb.ac.id ${ }^{3}$, \\ metaamalia09@gmail.com ${ }^{4}$ \\ ${ }^{*}$ Corresponding author
}

Kata Kunci:

Asap cair; Colletotrichum sp.; Kakao; Antraknosa

\begin{abstract}
ABSTRAK
Telah dilakukan penelitian peracunan media dengan asap cair pada pertumbuhan jamur Colletotrichum sp. penyebab busuk buah kakao, Penelitian ini bertujuan untuk mengetahui pengaruh konsentrasi asap cair terhadap pertumbuhan jamur Colletotrichum sp. penyebab penyakit busuk buah kakao. Penelitian ini menggunakan Rancangan Acak Lengkap (RAL) dengan faktor tunggal dan parameter yang diamati adalah penekanan diameter koloni, kerapatan spora, dan daya kecambah. Variabel pada penelitian ini adalah konsentrasi asap cair $(A O=$ Kontrol, $A 1=$ asap cair 0,02\%, $A 2=$ asap cair $0,04 \%, A 3=$ asap cair $0,08 \%, A 4=$ asap cair $0,16 \%, A 5$ $=$ asap cair 0,32\%) diuji terhadap koloni jamur Colletotrichum sp. Berdasarkan hasil penelitian dapat disimpulkan bahwa pemberian asap cair yang paling baik untuk menekan diameter koloni jamur Colletotrichum sp. adalah pada konsentrasi $0,32 \%$ dengan penghambatan pertumbuhan jamur 29,13\%. Selain itu, pemberian asap cair dapat menghambat pembentukan spora Colletotrichum sp. yang menyebabkan semakin kecilnya kerapatan spora yang terbentuk dengan pemberian konsentrasi $0,32 \%$ sebesar $0,1875 \times 10^{6}$. Sedangkan konsentrasi asap cair 0,32\% sangat bagus untuk menghambat daya kecambah (viabilitas) jamur Colletotrichum sp. yaitu sebesar $35,41 \%$.
\end{abstract}

\section{PENDAHULUAN}

Kakao (Theobroma cacao L.) merupakan salah satu tanaman perkebunan yang memiliki nilai ekonomis dan peluang pasarnya masih cukup besar, namun pengembangannya secara luas masih menghadapi hambatan yakni adanya serangan hama dan penyakit. Kalimantan Barat merupakan salah satu sentra produksi kakao terbesar di Kalimantan namun dalam beberapa tahun terakhir produktivitas kakao mengalami penurunan yang berkisar antara $10-30 \%$ yang diakibatkan oleh serangan jamur pathogen Colletotrichum gloeosporioides yang merupakan salah satu patogen laten yang dapat menginfeksi tanaman kakao dan juga menginfeksi buah-buahan seperti alpukat, mangga, pepaya, jambu biji, markisa, jeruk, apel, anggur dan jambu mete (Tasiwal, 2008). Luas perkebunan kakao pada 
tahun 2008 sekitar 9.583 ha dengan produksi 2.081 ton dan rata-rata produktivitasnya hanya 0,2 ton/ha (Badan Pusat Statistik, 2008).

Produktivitas tanaman kakao saat ini terbilang rendah jika dibandingkan dengan potensi maksimal yang dapat dicapai dengan luasan tanaman kakao. Tanaman kakao di Indonesia sebanyak 94\% dimiliki oleh petani rakyat dengan kondisi tanaman kakao yang berumur tua dan terserang OPT. Penggunaan pestisida sintetik sebagai pengendali OPT seperti patogen tanaman dapat meningkatkan hasil pertanian, sehingga menjaga stabilitas hasil dan kualitas hasil. Namun demikian, pemakaian yang terus menerus dapat menyebabkan patogen toleran terhadap pestisida, munculnya strain baru dan dampak negatif pada lingkungan serta dapat merusak kesehatan manusia karena meninggalkan residu pada tanaman, maupun pada produksi (Aisyah, Juli, \& Pari, 2013).

Mengingat efek samping yang ditimbulkan oleh penggunaan pestisida di atas, maka perlu dikembangkan pestisida yang bersifat mudah terdegradasi secara alami, bersifat toksik terhadap organisme pengganggu tanaman sasaran tetapi tidak bersifat toksik terhadap manusia dan ternak di sekitarnya, tidak mencemari lingkungan dan tidak berbahaya bagi kesehatan manusia (Aisyah, Juli, \& Pari, 2013). Penelitian tentang pestisida, fungisida dan insektisida alternatif telah banyak dilakukan diantaranya memanfaatkan Trichoderma spp. (Cikita, Khotimah, \& Linda, 2016), minyak cengkeh dan sereh dapur (Suryaningsih, Sudana, \& Suada, 2015), minyak kayu manis, serai wangi dan cengkeh (Alberida, Eliza, \& Lova, 2014), asap cair (Melani, 2020; Zuanif \& Despita, 2019; Praja et al., 2021; Pangestu, Suswanto, \& Supriyanto, 2014; Aisyah, Juli, \& Pari, 2013).

Pemanfaatan asap cair untuk menghambat jamur pathogen telah banyak dilakukan. Chalermsan \& Peerapan (2009) melaporkan bahwa asap cair mampu menghambat pertumbuhan Pythium sp., Sclerotium oryzae dan Rhizoctonia solani pada konsentrasi $2 \%$, sedangkan Choanephora cucurbitarum, Colletotrichum gloeosporioides dan Helminthosporium maydis dapat dihambat pada konsentrasi $>2 \%$ yaitu $3-4 \%$. Komponen terbesar yang terdapat dalam asap cair yang merupakan asam cuka memiliki efisiensi antijamur yang sangat tergantung pada kandungan senyawa fenolik di dalamnya. Hal ini telah dikonfirmasi oleh Mitsuyoshi et al. (2002) melalui penghambatan pertumbuhan jamur utama.

Penelitian asap cair dari tempurung kelapa untuk menghambat pertumbuhan cendawan Colletotrichum sp. pada tanaman kakao belum dilakukan baik secara in vitro maupun in vivo. Oleh karena itu, penelitian ini penting untuk dilakukan walaupun penelitian sebelumnya telah dilakukan dengan penerapan asap cair pada tanaman kakao untuk penyakit antraknosa yang disebabkan oleh jamur Phytophthora palmivora (Yunita, Suswanto, \& Sarbino, 2018) dan Phytophthora sp. (Pangestu, Suswanto, \& Supriyanto, 2014). Pada penelitian ini dititikberatkan pada kajian kemampuan asap cair tempurung kelapa untuk menghambat pertumbuhan jamur Colletotrichum sp. yang diisolasi dari buah kakao secara in vivo, sehingga penelitian ini dilakukan bertujuan untuk mengetahui pengaruh konsentrasi asap cair terhadap pertumbuhan jamur Colletotrichum sp. penyebab penyakit busuk buah kakao.

\section{METODE PENELITIAN}

\section{Alat dan Bahan Penelitian}

Alat yang digunakan dalam penelitian ini adalah petridish, jarum ose, bunsen, alumunium foil, cling rap, spatula, erlenmeyer, panci, kompor gas, beaker glass, neraca analitik, mikroskop binokuler, jangka sorong, haemacytometer. Pada penelitian ini digunakan bahan-bahan antara lain buah kakao, aquadest, Potato Dextrose Agar (PDA), asap cair, spiritus, dan alkohol.

\section{Rancangan Penelitian}

Rancangan penelitian ini adalah Rancangan Acak Lengkap (RAL) yang dibagi dalam 6 perlakuan. Pengulangan yang dilakukan untuk setiap perlakuan pada penelitian ini adalah sebanyak 4 kali. Perlakuan-perlakuan didalam penelitian ini adalah: 


$$
\begin{array}{ll}
\text { A0 } & =\text { Kontrol } \\
\text { A1 } & \text { = asap cair } 0,02 \% \\
\text { A2 } & \text { = asap cair } 0,04 \% \\
\text { A3 } & =\text { asap cair } 0,08 \% \\
\text { A4 } & =\text { asap cair } 0,16 \% \\
\text { A5 } & =\text { asap cair } 0,32 \%
\end{array}
$$

Setiap perlakuan diulang empat kali sehingga terdapat 24 petridish.

\section{Penyediaan Isolat Jamur Colletotrichum sp.}

Buah kakao yang terkena penyakit busuk buah akibat Colletotrichum sp. diperoleh dari kebun percobaan tanaman kakao di Balai Proteksi Tanaman Perkebunan Pontianak kemudian dibawa ke Laboratorium Penyakit di Balai Proteksi Tanaman Perkebunan Pontianak untuk isolasi dan diperbanyak dengan menggunakan prosedur sebagai berikut : Buah yang menunjukkan gejala busuk dicuci bersih menggunakan air yang mengalir. Kemudian bagian buah yang menunjukkan gejala busuk dipotong antara bagian sehat dan bagian yang sakit dengan ukuran $5-10 \mathrm{~mm}$, kemudian direndam di dalam larutan kloroks $70 \%$ selama 15 detik, lalu dibilas dengan aquades steril dan ditiriskan. Potongan kakao diisolasi pada medium PDA dan diinkubasi selama 9 hari pada suhu kamar.

\section{Pembuatan dan Penyiapan Asap Cair}

1. Proses Pembuatan Asap Cair

Sebelum dimasukkan ke tungku pemanasan (pirolisis), terlebih dahulu tempurung kelapa ini dibersihkan dari kotoran dan sabut yang tertinggal. Kemudian tempurung kelapa dipecah menjadi beberapa bagian. Selanjutnya dilakukan pengeringan dengan cara penjemuran untuk mengurangi kadar air pada tempurung kelapa. Kemudian tempurung kelapa dimasukkan ke dalam tungku pembakaran, kemudian dinyalakan. Proses pemanasan akan mengeluarkan asap melalui pipa yang terendam dalam kondensor. Asap yang terkondensasi di dalam drum berisi air akan mengembun dan mengeluarkan cairan hasil kondensasi. Cairan yang keluar merupakan campuran heterogen antara asap cair dan tar ditampung pada wadah yang sudah disediakan. Proses pemanasan berakhir jika asap cair tidak menetes lagi dalam wadah. Asap cair yang sudah dihasilkan diendapkan selama $7-10$ hari agar tar dan senyawa yang tidak terlarut mengendap. Saring asap cair yang sudah diendapkan dan siap digunakan untuk menyemprot tanaman.

\section{Penyiapan Asap Cair}

Asap cair grade 3 tidak dapat digunakan untuk pengawet makanan, karena masih banyak mengandung tar yang bersifat karsinogen. Penyiapan ekstrak asap cair dilakukan dengan mengencerkan asap cair grade 3 sesuai konsentrasi yaitu $0,02 \% ; 0,04 \% ; 0,08 \% ; 0,16 \% ; 0,32 \%$.

\section{Penekanan Diameter Koloni}

Pengujian daya anti cendawan untuk penekanan diameter koloni dilakukan dengan cara memberikan larutan uji asap cair sesuai konsentrasi uji $(0,02 \% ; 0,04 \% ; 0,08 \% ; 0,16 \% ; 0,32 \%$, serta kontrol) ke dalam larutan PDA yang sudah steril, sambil dihomogenkan lalu dituang ke dalam cawan petri. Setelah media dingin (padat), pada bagian tengah medium tersebut diletakkan potongan biakan jamur Colletotrichum sp. ukuran 0,5 cm dan diinkubasi pada suhu kamar. Parameter yang diamati adalah diameter pertumbuhan Colletotrichum sp. sejak hari pertama isolasi sampai pertumbuhan jamur Colletotrichum sp. pada kontrol memenuhi cawan petri. Persentase penghambatan dihitung dengan rumus (Noveriza \& Miftakhuromah, 2010):

$$
x=\frac{b-a}{a} \times 100 \%
$$

\footnotetext{
$x \quad=$ persentase penghambatan pertumbuhan koloni

$a \quad=$ diameter pertumbuhan pada perlakuan

$b \quad=$ diameter pertumbuhan pada kontrol
} 


\section{Penghitungan Kerapatan Spora}

Jumlah spora yang dihitung dengan metode hitungan mikroskop langsung menggunakan alat haemocytometer. Untuk menghitung kerapatan spora dilakukan dengan cara mengambil spora yang tumbuh pada setiap cawan petri. Kemudian dimasukkan ke dalam tabung reaksi ditambahkan $10 \mathrm{ml}$ aquades steril dan dihomogenkan. Selanjutnya diteteskan suspensi $0,1 \mathrm{ml}$ ke sisi depan haemocytometer dan $0,1 \mathrm{ml}$ ke sisi belakang haemacytometer. Jumlah spora dihitung dengan mencari rata-rata jumlah spora dari kotak sampel yang diamati.

$$
\begin{array}{ll}
S & =\text { jumlah spora } \times 0,25 \times 10^{6} \\
S & =\text { kerapatan spora } \\
0,25 & =\text { ukuran standar haemacytometer }
\end{array}
$$

\section{Uji Perkecambahan Spora Jamur}

Uji dilakukan dengan cara menginokulasi suspensi inokulum patogen dengan kerapatan spora yang telah dihitung, diinkubasikan selama $12 \mathrm{jam}$. Daya kecambah dihitung dengan rumus sebagai berikut (Gabriel \& Riyatno, 1989):

$$
\begin{array}{cc} 
& v=\frac{g}{g+u} \times 100 \% \\
v & =\text { perkecambahan spora } \\
g & =\text { jumlah spora yang berkecambah } \\
u & =\text { jumlah spora yang tidak berkecambah }
\end{array}
$$

\section{HASIL DAN PEMBAHASAN}

\section{Isolasi dan Karakterisasi Jamur dari Buah Kakao}

Hasil dan Identifikasi jamur dari buah kakao di Balai Proteksi Tanaman Perkebunan Pontianak menunjukkan gejala penyakit antraknosa, yaitu jamur Colletotrichum sp. Hasil pengamatan menunjukkan ciri-ciri jamur Colletotrichum sp. adalah konidia berbentuk elips berwarna abu-abu, meruncing pada salah satu ujungnya, secara visual koloni jamur berwarna putih. Pada penelitian ini jamur Colletotrichum sp. didapat dari kebun percontohan di Balai Proteksi Tanaman Perkebunan Pontianak. Gambar 1. menunjukkan diameter koloni jamur Colletotrichum sp. yang diisolasi dari buah kakao.

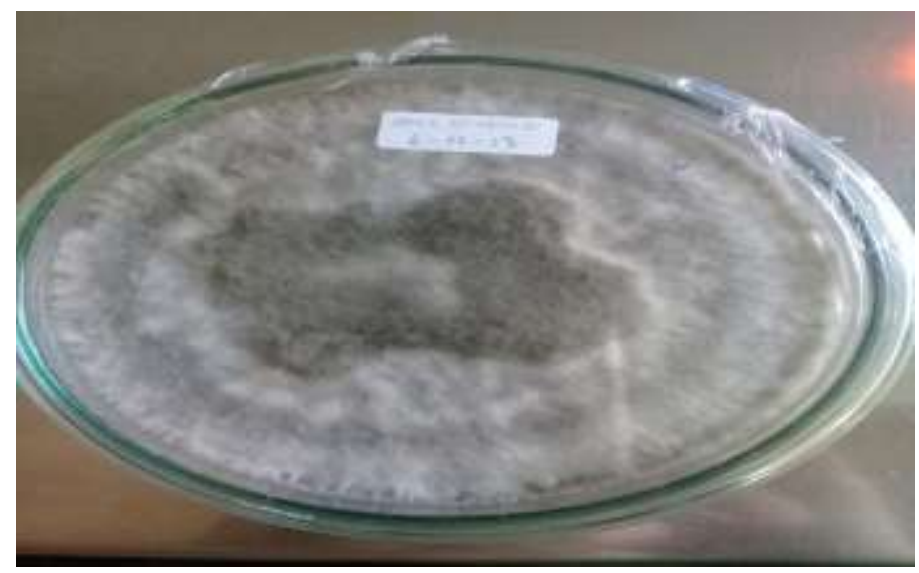

Gambar 1. Koloni Jamur Colletotrichum sp. Hasil Isolasi

\section{Penekanan Diameter Koloni}

Pengamatan pada pertumbuhan miselium dilakukan dengan cara mengamati waktu yang dibutuhkan sejak muculnya miselium sampai pertumbuhan miselium optimal dengan dinyatakan HSI (Hari Setelah Inokulasi). Berdasarkan hasil penelitian ini, pertumbuhan miselium optimal pada hari ketujuh. Dari data tersebut selanjutnya dilakukan perhitungan analisis keragaman dan hasil analisis keragaman dapat dilihat pada Tabel 1. 


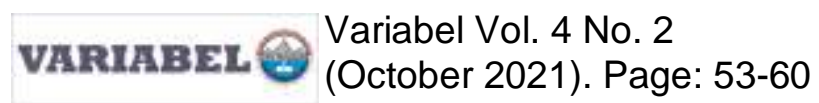

Tabel 1. Analisis Keragaman Pengaruh Pemberian Asap Cair pada Media PDA

\begin{tabular}{|c|c|c|c|c|c|c|}
\hline \multirow[t]{2}{*}{ Sumber Keragaman } & \multirow{2}{*}{$\begin{array}{c}\text { Derajat } \\
\text { Bebas }\end{array}$} & \multirow{2}{*}{$\begin{array}{c}\text { Jumlah } \\
\text { Kuadrat }\end{array}$} & \multirow{2}{*}{$\begin{array}{c}\text { Kuadrat } \\
\text { Tengah }\end{array}$} & \multirow[t]{2}{*}{$F_{\text {hitung }}$} & \multicolumn{2}{|c|}{$F_{\text {tabel }}$} \\
\hline & & & & & $5 \%$ & $1 \%$ \\
\hline Perlakuan & 5,00 & 16,0175 & 3,2035 & $23,23 * *$ & 2,77 & 4,25 \\
\hline Galat & 18,00 & 2,4825 & 0,1379 & & & \\
\hline Total & 23,00 & 18,5 & & & & \\
\hline
\end{tabular}

Berdasarkan hasil analisis keragaman pada Tabel 1 menunjukkan bahwa perlakuan pemberian asap cair memberikan pengaruh yang sangat nyata terhadap pertumbuhan jamur Colletotrichum sp. Untuk melihat perbedaan taraf perlakuan asap cair terhadap penekanan diameter koloni jamur Colletotrichum sp. maka dilakukan uji BNJ pada taraf kepercayaan $5 \%$ seperti pada Tabel 2.

Tabel 2. Uji BNJ Pengaruh Pemberian Asap Cair terhadap Rerata Penekanan Jamur Colletotrichum

\begin{tabular}{ccc}
\hline Perlakuan & Rerata & Beda \\
\hline A0 & 7,725 & $\mathrm{a}$ \\
A1 & 7,15 & $\mathrm{ab}$ \\
A2 & 6,8 & $\mathrm{abc}$ \\
A3 & 5,775 & abcd \\
A4 & 5,85 & abcd \\
A5 & 5,475 & abcd \\
\hline BNJ 5 $\%=1,67$ & &
\end{tabular}

Keterangan: Angka-angka yang diikuti huruf yang sama tidak berbeda nyata menurut Uji Beda Nyata (BNJ) pada taraf $5 \%$.

Hasil analisis BNJ menunjukkan bahwa perlakuan konsentrasi asap cair berbeda nyata pengaruhnya menurut BNJ 5\%, dapat diketahui bahwa hasil perbandingan nilai rata antara penghambatan pertumbuhan jamur dengan uji BNJ menunjukkan perlakuan konsentrasi $0,02 \%, 0,04 \%, 0,08 \%, 0,16 \%$ dan $0,32 \%$ berpengaruh sangat nyata antara satu dengan yang lainnya. Tiap perlakuan dapat menghambat pertumbuhan jamur Colletotrichum sp. sesuai dengan besar konsentrasi asap cair yang digunakan, semakin besar konsentrasi asap cair maka semakin besar pula penghambatan jamur Colletotrichum sp. begitu pula sebaliknya. Adapun besarnya penghambatan asap cair terhadap jamur Colletotrichum sp. dapat dilihat pada Tabel 3.

Tabel 3. Hasil Besaran Penghambatan Asap Cair terhadap Jamur Colletotrichum sp.

\begin{tabular}{ccc}
\hline Perlakuan & Perlakuan & Penghambatan $(\%)$ \\
\hline A0 & A0 & 0 \\
A1 & A1 & 7,44 \\
A2 & A2 & 11,97 \\
A3 & A3 & 25,24 \\
A4 & A4 & 24,27 \\
A5 & A5 & 29,13 \\
\hline
\end{tabular}

Tabel 3 menunjukkan bahwa pemberian asap cair pada media agar memberikan pengaruh terhadap pertumbuhan jamur Colletotrichum sp. yang dilihat dari penghambatan yang semakin tinggi seiring dengan bertambahnya konsentrasi dari asap cair. Konsentrasi asap cair yang menyebabkan penghambatan terbesar sebesar $29,13 \%$ diperoleh pada konsentrasi asap cair 0,32\%, sedangkan konsentrasi 0,02\% menyebabkan penghambatan pertumbuhan jamur Colletotrichum sp. sebesar 7,44\% pada 7 hari setelah inokulasi. Hal ini sesuai dengan penelitian yang dilakukan oleh Pangestu, Suswanto, \& Supriyanto (2014) dan Mahmud et al. (2021) bahwa peningkatan konsentrasi asap cair juga diikuti oleh peningkatan penghambatan pertumbuhan jamur. Senyawa racun yang terdapat pada asap cair, yaitu fenol diduga bekerja secara sinergis dengan senyawa asam dan karbonil yang terdapat pada asap cair sebagai senyawa antimikroba (Mahmud et al., 2021). Selain fenol, senyawa yang dapat berperan juga sebagai antimikroba adalah alkohol dan asam asetat (Melani, 2020). 
Alkohol, fenol, dan asam asetat diduga memiliki fungsi sinergis untuk mendenaturasi protein dan menghidrolisis lipid, sehingga dapat merusak membran sel dan menginaktivasi enzim jamur. Kerusakan protein dan lipid pada membran sitoplasma sel, menyebabkan permeabilitas membran menjadi terganggu sehingga menyebabkan membran menjadi tidak bersifat semi-permeabel. Terganggunya fungsi membran juga akan mempengaruhi kerja enzim permease yang menjadi tempat keluar masuknya senyawa-senyawa tertentu ke dalam sel. Akitivitas biologis dan fisiologis jamur yang rusak lama kelamaan akan menyebabkan kematian pada jamur (Melani, 2020; Agustina, 2020).

Efisiensi anti jamur asap cair sangat tergantung pada kandungan senyawa fenolik yang terkandung di dalam asap cair dan ini telah dikonfirmasi melalui pertumbuhan penghambatan jamur utama (Mitsuyoshi et al., 2002). Nakajima et al. (1993) melaporkan bahwa konsentrasi asap cair kurang dari $1 \%$ akan mengaktifkan pertumbuhan tanaman dan asap cair yang disemprotkan ke tanah mampu mengurangi mikroorganisme patogen dan arthropoda pada tanah.

\section{Perhitungan Kerapatan Spora}

Penghitungan kerapatan Spora menggunakan haemacytometer, dimana pada haemacytometer ada 2 bidang pandang. Bidang pandang 1 dihitung sebanyak 5 kotak besar. Masing-masing diulang sebanyak 2 kali. Adapun perhitungan spora dapat dilihat pada Tabel 4. Gambar 2 menunjukkan kerapatan spora dengan berbagai perlakuan.

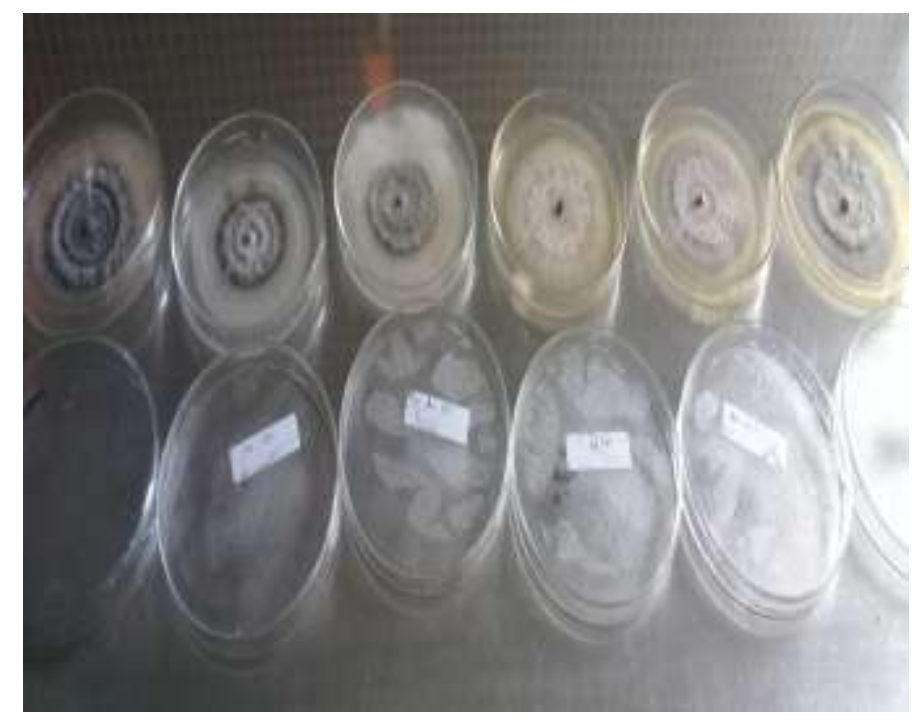

Gambar 2. Kerapatan Spora Jamur Colletotrichum sp. dengan Berbagai Konsentrasi Asap Cair

Tabel 4. Perhitungan Kerapatan Spora Jamur Colletotrichum sp. terhadap Konsentrasi Asap Cair

\begin{tabular}{cccc}
\hline Perlakuan & Ulangan I & Ulangan II & Rerata \\
\hline A0 & $1,375 \times 10^{6}$ & $1,125 \times 10^{6}$ & $1,25 \times 10^{6}$ \\
A1 & $0,5 \times 10^{6}$ & $0,75 \times 10^{6}$ & $0,625 \times 10^{6}$ \\
A2 & $0,375 \times 10^{6}$ & $0,375 \times 10^{6}$ & $0,375 \times 10^{6}$ \\
A3 & $0,25 \times 10^{6}$ & $0,375 \times 10^{6}$ & $0,3125 \times 10^{6}$ \\
A4 & $0,25 \times 10^{6}$ & $0,375 \times 10^{6}$ & $0,3125 \times 10^{6}$ \\
A5 & $0,125 \times 10^{6}$ & $0,25 \times 10^{6}$ & $0,1875 \times 10^{6}$ \\
\hline
\end{tabular}

Daya hambat asap cair terhadap pembentukan spora Colletotrichum sp. dengan perlakuan asap cair menyebabkan jumlah spora lebih sedikit jika dibandingkan dengan spora pada kontrol, karena asap cair mampu menghambat pertumbuhan spora jamur Colletotrichum sp. Pada Tabel 4 dapat dilihat kerapatan spora pada media yang tidak diberi asap cair (kontrol) sebesar $1,25 \times 10^{6}$, sedangkan pada konsentrasi asap cair $0,32 \%$ mengalami penurunan kerapatan spora menjadi $0,1875 \times 10^{6}$. Jumlah sporangium pada konsentrasi tertinggi $0,32 \%$ asap cair termasuk rendah jika dibandingkan konsentrasi yang lain. Fenol sebagai antimikrobia dapat mendenaturasi enzim atau bereaksi dengan asam amino 
yang bertanggung jawab pada regenerasi spora (Pangestu, Suswanto, \& Supriyanto, 2014; Mahmud et al., 2021).

Fenol merupakan antiseptik dan desinfektan yang efektif terhadap bentuk vegetatif bakteri gram positif dan gram negatif, mikrobakteria, beberapa jamur dan virus, tetapi kurang efektif dalam bentuk spora (Sumarni, 2010). Asam organik menyebabkan penurunan $\mathrm{pH}$ lingkungan hidup mikrobia. Pada $\mathrm{pH}$ lingkungan yang asam, asam asetat dapat menyebabkan denaturasi enzim dan ketidakstabilan permeabilitas membran sel mikrobia, sehingga menghambat pertumbuhan dan daya hidup sel mikrobia (Sumarni, 2010).

\section{Viabilitas Spora}

Pengamatan viabilitas spora dilakukan pada waktu 12 jam setelah penetesan suspensi. Dimana pengamatan diulang sebanyak 2 kali pada setiap perlakuan. Adapun pengamatan viabilitas spora dapat dilihat pada Tabel 5.

Tabel 5. Perhitungan Viabilitas Spora Jamur Colletotrichum sp. terhadap Konsentrasi Asap Cair

\begin{tabular}{cccc}
\hline Perlakuan & Ulangan I & Ulangan II & Rerata \\
\hline A0 & $80 \%$ & $66,67 \%$ & $73,33 \%$ \\
A1 & $50 \%$ & $71,43 \%$ & $60,71 \%$ \\
A2 & $40 \%$ & $62,5 \%$ & $51,25 \%$ \\
A3 & $41,67 \%$ & $50 \%$ & $45,83 \%$ \\
A4 & $33,33 \%$ & $42,86 \%$ & $38,09 \%$ \\
A5 & $33,33 \%$ & $37,5 \%$ & $35,41 \%$ \\
\hline
\end{tabular}

Pada Tabel 5 dapat dilihat jika tanpa pemberian asap cair, daya kecambah spora (viabilitas) Colletotrichum sp. adalah $73,33 \%$, sedangkan dengan penambahan konsentrasi asap cair $0,32 \%$, daya kecambah Colletotrichum sp. mengalami penurunan menjadi 35,41\%. Ini karena asap cair dari bahan tempurung kelapa memiliki sifat antifungi karena di dalamnya terkandung senyawa-senyawa fungsional seperti alkohol, fenol, dan asam organik. Efek antimikroba asam dari asap cair diduga secara langsung dapat mengasamkan sitoplasma, merusak permukaan membran sel dan struktur komponen sel, serta hilangnya fungsi transpor aktif makanan (Ray \& Sandine, 1993). Adapun mekanisme aktivitas senyawa antimikrobia fenol, antara lain reaksi dengan membran sel yang menyebabkan terganggunya kerja permeabilitas membran sel, inaktivasi enzim-enzim esensial, perusakan fungsional material genetik, bekerja sebagai penghidrolisis lipid sehingga merusak membran sel (Melani, 2020).

\section{KESIMPULAN}

Berdasarkan hasil penelitian dapat disimpulkan bahwa pemberian asap cair yang paling baik untuk menekan diameter koloni jamur Colletotrichum sp. adalah pada konsentrasi 0,32\% dengan penghambatan pertumbuhan jamur $29,13 \%$. Selain itu, pemberian asap cair dapat menghambat pembentukan spora Colletotrichum sp. yang menyebabkan semakin kecilnya kerapatan spora yang terbentuk dengan pemberian konsentrasi $0,32 \%$ sebesar $0,1875 \times 10^{6}$. Adapun konsentrasi asap cair $0,32 \%$ sangat baik untuk menghambat daya kecambah (viabilitas) jamur Colletotrichum sp, yaitu sebesar $35,41 \%$.

\section{DAFTAR PUSTAKA}

Agustina, N.A. (2020). Efektivitas Daya Hambat Asap Cair Tempurung Kelapa (Cocus nucifera) Terhadap Pertumbuhan Jamur Ganoderma boninense. Agroprimatech, 3(2), 79-82.

Aisyah, I., Juli, N. \& Pari, G. (2013). Pemanfaatan Asap Cair Tempurung Kelapa untuk Mengendalikan Cendawan Penyebab Penyakit Antraknosa dan Layu Fusarium pada Ketimun, Jurnal Penelitian Hasil Hutan, 31(2), 170-178. 
Alberida, H., Eliza, \& Lova, R.N. (2014). Pengaruh Minyak Atsiri terhadap Pertumbuhan Colletotrichum gloeosporioides (Penz.) Sacc. Penyebab Penyakit Antraknosa Buah Pepaya (Carica papaya L.) Secara In Vitro. Jurnal Sainstek, 6(1), 57-64, Juni 2014.

Badan Pusat Statistik. (2008). Statistik Perkebunan Kakao. Kalimantan Barat: BPS.

Chalermsan, Y. \& Peerapan, S. (2009). Wood Vinegar: By-Product From Rural Charchoal Kiln and Its Role in Plant Protection. Asian Journal Food and Agro-Industry. International Conference on the Role of Universities in Hands-On Education, 167-174.

Cikita, D., Khotimah, S., \& Linda, R. (2016). Uji Antagonis Trichoderma spp. terhadap Phytophthora palmivora Butl. Penyebab Penyakit Busuk Buah Kakao (Theobroma cacao L.). Jurnal Protobiont, 5(3), 59-65.

Gabriel, B.P. \& Riyatno. (1989). Metarhizium anisopliae (Metch) Sor: Taksonomi, paotologi, Produksi dan Aplikasinya. Direktorat Perlindungan Tanaman Perkebunan. Departemen Pertanian.

Mahmud, Y., Lististio, D., Irfan, M., \& Zam, S.I. (2021). Efektivitas Asap Cair Tandan Kosong Kelapa Sawit untuk Mengendalikan Ganoderma Boninese dan Curvularia Sp. in Vitro. Jurnal Pertanian Presisi, 5(1), 24-39.

Melani, D. (2020). Efektivitas Asap Cair terhadap Colletotrichum capsici pada Tanaman Cabai Merah (Capsicum annum L.). Jurnal AgroSainTa, 4(2), 85-96.

Mitsuyoshi, Y., Madoka, N., Keko, H., Tatsuro, O., \& Akira, S. (2002). Termiticidal activity of wood vinegar, its components and their homologues. Journal of Wood Science, 48(4), 338-342.

Nakajima, S., Tsuji, M., Iwasaki, K., Yoshida, T., \& Fukumoto, Y. (1993). Effect of wood vinegars on the growth of tomato, eggplant and muskmelon seedlings. Research Reports of the Kochi University, Agricultural Science, 42, 59-68.

Noveriza, R. \& Miftakhuromah. (2010). Efektivitas Ekstrak Metanol Daun Salam (Eugenia polyantha) dan Daun Jeruk Purut (Cytrus histrix) sebagai Antijamur pada Pertumbuhan Fusarium oxysporum. Jurnal Littri, 16(1), 6-11.

Pangestu, E., Suswanto, I. \& Supriyanto. (2014). Uji Penggunaan Asap Cair Tempurung Kelapa dalam Pengendalian Phytophthora sp. Penyebab Penyakit Busuk Buah Kakao Secara In Vitro. J. Perkebunan \& Lahan Tropika, 4(2), 39-44.

Praja, K. Natalia, J., Kencana, P.K.D., \& Arthawan, I.G.K.A. (2021). Pengaruh Konsentrasi Asap Cair Bambu Tabah (Gigantochloa nigrociliata Buse-Kurz) dan Lama Perendaman Terhadap Kesegaran Pisang Cavendish (Musa acuminata). Jurnal Beta (Biosistem Dan Teknik Pertanian), 9(1), 45-55.

Ray, B. \& Sandine, W.E. (1993). Acetic, Propionic and Lactic Acid of Starter Culture Bacteria as Biopreservatives dalam Ray, B., Daeschel M (eds) : Food Biopreservatives of Microbial Origin. Boca Raton: CRC Press. p. 105 - 132.

Sumarni. (2010). Pengujian Daya Racun Asap Cair Tempurung Kelapa (Cocos nucifera L) terhadap Serangan Cendawan Pelapuk Kayu Schizophyllum commune Fries. Skripsi. Pontianak: Fakultas Kehutanan, Universitas Tanjungpura.

Suryaningsih, K.I., Sudana, I.M., \& Suada, I.K. (2015). Pengendalian Penyakit Antraknosa (Colletotrichum gloeosporioides Penz) pada Buah Jeruk Siam (Citrus nobilis var. microcarpa) dengan Menggunakan Minyak Atsiri Cengkeh dan Sereh Dapur. Jurnal Agroekoteknologi Tropika, 4(1), 16-24. ISSN: 2301-6515.

Tasiwal, V. (2008). Studies on Anthracnose a Postharvest Disease of Papaya. Department of Plant Pathology College of Agriculture, Dharwad University of Agricultural Sciences. Dharwad. 580005.

Yunita, Suswanto, I., \& Sarbino. (2018). Pengaruh Asap Cair Tempurung Kelapa terhadap $P$. palmivora Penyebab Penyakit Busuk Buah pada Kakao. Jurnal Perkebunan dan Lahan Tropika, 8(2), 91-97.

Zuanif, V. \& Despita, R. (2019). Uji Kemampuan Asap Cair secara in Vitro dan in Vivo untuk Penyakit Antraknosa (Colletotrichum capsici) pada Tanaman Cabai (Capsicum annum L). Jurnal Agriekstensia, 18(2),160-169. 